The eastern Himalaya is an important phytogeographical area with a rich diversity of flora and fauna harbouring many endemic and endangered elements. Endemic floristic elements of a country or OPEN ACCESS geographical region throw light on the biogeography of the area, centres of speciation, areas of extinction and adaptive evolution of the flora occurring in the area (Ahmedullah \& Nayar 1987). The family Zingiberaceae, represented by 53 genera and about 1200 species, is distributed mainly in the tropics and subtropics with its centre of distribution in the Indo-Malayan region (Sabu 2006). Amomum Roxb. is the second largest genus of the family, represented by 150 species in the world (Tripathi \& Prakash 1999). In India, the members of the genus are mainly distributed in northeastern India, peninsular India and Andaman \& Nicobar Islands (Thomas \& Sabu 2012) with 22 species with the major centre of distribution in northeastern India (Thomas et al. 2010). As a part of revisionary work on Indian Amomum, we found Amomum kingii during field explorations in eastern Sikkim in large cardamom cultivated fields of Pangthang and the nearby field station of the Indian Cardamom Research Institute.

The species was first described by Baker (1892) based on the King's collection from Sikkim-Himalaya.

\section{REDISCOVERY OF AMOMUM KINGII BAKER (ZINGIBERACEAE): ENDEMIC AND HIGHLY THREATENED GINGER FROM SIKKIM, INDIA}

\section{V.P. Thomas ${ }^{1} \&$ M. Sabu ${ }^{2}$}

${ }^{1}$ Department of Botany, Catholicate College, Pathanamthitta, Kerala 689645 , India

${ }^{2}$ Department of Botany, University of Calicut, Kerala 673635, India ${ }^{1}$ amomum@gmail.com, ${ }^{2}$ msabu9gmail.com (corresponding author)

Subsequently, Schumann (1904) included it as a distinct species with a remark on the uncertainty of the occurrence of species and adopted the descriptions of Baker. In the Flora of Bhutan, Smith (1994) included A. kingii and mentioned that it is an imperfectly known species described from Sikkim and no material has been seen. Kumar (2001) while studying the Zingiberaceae of Sikkim included this taxon based on existing literature, but he could not locate any live specimens and suggested a critical study of species based on live collections. Since Baker (1892), no live specimens were located in the field or deposited in any of the herbaria.

The voucher specimens of the same were deposited in the Herbarium, Department of Botany, University of Calicut, Kerala (CALI). So far, this is collected only from Pangthang in eastern Sikkim. The present report constitutes the rediscovery of this interesting, narrow
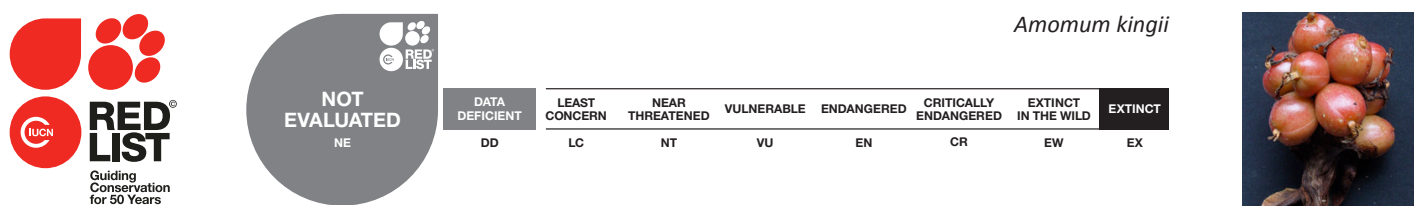

DOI: http://dx.doi.org/10.11609/JoTT.03589.7034-6

Editor: B. Ravi Prasad Rao, Sri Krishnadevaraya University, Anantapur, India.

Date of publication: 26 March 2015 (online \& print)

Manuscript details: Ms \# 03589 | Received 18 April 2013 | Final received 21 November 2014 | Finally accepted 10 March 2015

Citation: Thomas, V.P. \& M. Sabu (2015). Rediscovery of Amomum kingii Baker (Zingiberaceae): endemic and highly threatened ginger from Sikkim, India. Journal of Threatened Taxa 7(3): 7034-7036; http://dx.doi.org/10.11609/JoTT.03589.7034-6

Copyright: (C) Thomas \& Sabu 2015. Creative Commons Attribution 4.0 International License. JoTT allows unrestricted use of this article in any medium, reproduction and distribution by providing adequate credit to the authors and the source of publication.

Funding: Department of Biotechnology, New Delhi, for Financial support for the research Project (BT/PR/5275/PBD/16/917/ 2011 Dt. 15.03.2012).

Competing Interest: The authors declare no competing interests.

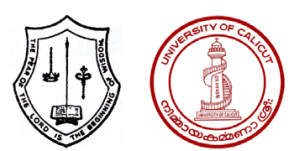

Acknowledgements: The authors are grateful to Deputy Director, Indian Cardamom Research Institute, Gangtok for providing the materials and Dr. U. Gupta, Dr. K.A. Saju and Mr. Manoj Banerjee (ICRI, Gangtok) for their help in various ways. 


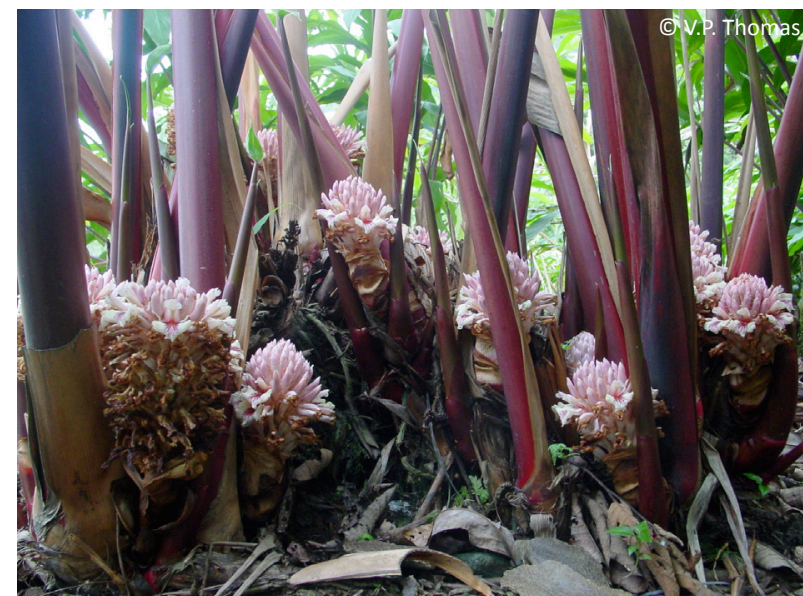

Image 1. Amomum kingii - Inflorescences

endemic species after a lapse of over a century from Sikkim. A detailed taxonomic account of the taxon has been provided to facilitate its easy identification.

Amomum kingii Baker, in Hook. f., Fl. Brit. India 6: 241. 1892; K. Schum. in Engl., Pflanzenr. 4(46): 241. 1904; J.N. Mitra, FI. PI. E. India 1: 254. 1958; S.K. Jain and V. Prakash, Rheedea 5: 157. 1995; S. Kumar, Zingiberaceae of Sikkim 16. 2001 (Images 1 \& 2).

Rhizome stout, c. $5 \mathrm{~cm}$ thick, covered with coriaceous, glabrous sheaths. Leafy shoots $200-350 \mathrm{~cm}$ tall; sheath c. $4 \mathrm{~cm}$ wide at base, maroon, lined with prominent parallel veins, margin membranous, glabrous externally. Leaves 6-8 per tiller; lamina oblong-lanceolate, 55$120 \times 17.5-24 \mathrm{~cm}$, dark green above, powdery white beneath, base oblique, apex acuminate, glabrous on both surfaces; midrib pink, glabrous except a layer of hairs along the margin beneath; petiole $0.8-1.3 \mathrm{~cm}$ long, pale pink, puberulous inside, glabrous externally. Ligule entire, 1-1.5 cm long, coriaceous, dark maroon, margin ciliate, apex rounded, externally pubescent, dark maroon glandular structure present in adjoining portion of petiole and ligule. Inflorescence 13-25×4-7.5 $\mathrm{cm}$, radical, oblong; peduncle $5.5-9 \mathrm{~cm}$ long. Sheathing bract 8-9 per inflorescence, ovate, brown, 5-7×3-5 $\mathrm{cm}$, laterally fused with adjacent bracts, prominently veined, puberulous externally, glabrous within. Flower 4.5-5.7 cm long, white tinged with yellow, many blooms at a time. Bracts linear lanceolate, $3.5-3.9 \times 0.7-1 \mathrm{~cm}$, membranous, pale yellow, margin distantly ciliate, apex acute, pubescent externally, glabrous within. Bracteole highly reduced, represented by small rudimentary structures, irregular in shape, c. $0.2 \times 0.3 \mathrm{~cm}$, open or fused by ends, margin distantly ciliate, apex acute, glabrous. Calyx 3-toothed, $2.3-3.2 \times 0.8 \mathrm{~cm}$, white, membranous, lobes pubescent, cleft $1.2-1.4 \mathrm{~cm}$ deep, apex acute,

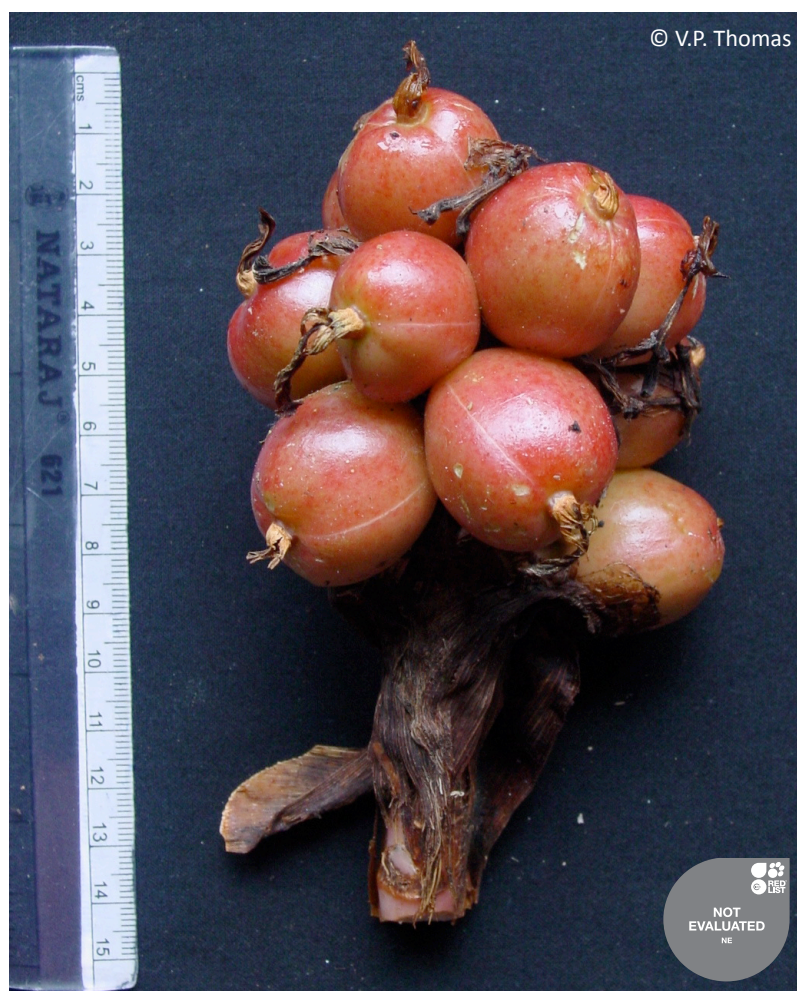

Image 2. Amomum kingii - Inflorescences

pubescent externally, glabrous within. Corolla tube $2.2-2.3 \mathrm{~cm}$ long, $0.4-0.5 \mathrm{~cm}$ wide at mouth, pale yellow, densely pubescent externally, pubescent within, densely towards mouth; dorsal corolla lobe oblong, 2.1-2.5×1.2$1.3 \mathrm{~cm}$, white tinged with pink, margin ciliate near base, apex hooded, densely pubescent externally, glabrous within; lateral corolla lobes oblong, 2-2.2×0.9-1.1 cm, white tinged with pink, margin ciliate towards base, apex form a folding, pubescent externally, glabrous within. Labellum obovate, 3-5×2.6-2.8 cm, obscurely 3-lobed, median lobe emarginate, cleft c. $0.5 \mathrm{~cm}$ deep, white tinged with yellow, centre with dark pink bands which arise from base, bands divides at different levels, basal part formed of red, margin crenulate, pubescent inside towards base. Lateral staminodes ribbon-like, 1.5-1.8 $\mathrm{cm}$ long, flat, tapering towards apex, pale yellow, lower part maroon, densely pubescent towards base, glabrous towards apex. Stamen $2.3-2.5 \mathrm{~cm}$ long; filament 0.5$0.6 \times 0.4-0.6 \mathrm{~cm}$, creamy white, pink towards base, pubescent externally, pubescent within; connective glandular hairy; crest obscurely tri-lobed with unequal lobbing, $1.3-1.5 \times 0.7-0.9 \mathrm{~cm}$, white, glabrous within, puberulous externally; anther 2-celled, thecae oblong, 1.1-1.3 cm, cream coloured, base sharply ending, apex diverging, margin glabrous, dehiscence complete, linear. Epigynous glands two, oblong, $0.6-0.7 \mathrm{~cm}$ long, 
cream coloured, rarely gland not completely separated. Ovary inferior, $0.5-0.7 \times 0.5-0.6 \mathrm{~cm}$, trigonous, glabrous externally; pedicel hairy; locules 3 ; ovules many on axile placentae, two in each row; style c. $3.6 \mathrm{~cm}$ long, glabrous; stigma c. $0.1 \mathrm{~cm}$, cup-shaped, white, mouth ciliate, opening apical. Infructescence c. $14 \mathrm{~cm}$ long, peduncle c. $7 \mathrm{~cm}$ long, 10-15 per spike. Capsule globose or spherical, $2.4-2.7 \times 2.5-2.6 \mathrm{~cm}$, smooth walled, red tinged with green, glabrous. Seeds many, $0.4-0.6 \times 0.3-$ $0.4 \mathrm{~cm}$, brown, aromatic, glabrous, arillate; aril white.

Specimens examined: 92731 (CALI), 23.viii.2004, Pangthang, East Sikkim District, Sikkim, India, coll. M. Sabu \& A.K. Pradeep; 92778 (CALI), 04.xi.2005, coll. E. Sanoj; 105504 (CALI), 22.viii.2006, coll. V.P. Thomas; 95505 (CALI), 07.v.2007, coll. V.P. Thomas \& Muhammed Nissar (Image 3).

Flowering \& Fruiting: March-August.

Ecology: In shaded places at high altitudes (above $1800 \mathrm{~m}$ ) in Sikkim.

Etymology: The species was described by Baker (1892) based on the collections of King and the specific epithet denotes the name of the collector.

Proposed IUCN status: The IUCN status (IUCN 2001; IUCN 2012) has been analyzed for the species and determined as Critically Endangered (CR B2ab(i,ii);D). The area of occupancy is estimated to be less than $10 \mathrm{~km}^{2}$ and known to exist only in a single location. A continuous decline in quality of habitat and extent of occurrence is noticed. The population size is estimated to number fewer than $\mathbf{5 0}$ mature individuals. Expansion of large cardamom plantations and other anthropogenic activities amplify pressure on the fragile habitat and existing individuals. All efforts to introduce it in the Calicut University Botanic Garden were in vain, probably due to altitudinal variation. Hence, adequate measures should be taken to protect this species through micropropagation and ex situ conservation in the gardens and conservatories at high altitudes. The species is identified as an excellent potential ornamental for high altitude gardens. Mass micropropagation and reintroduction of the species in the wild is also suggested. The narrow endemic distribution and various human activities have lead to the verge of extinction of the species. Thus it is imperative that steps be taken to conserve this Critically Endangered taxon.

\section{References}

Ahmedullah, M. \& M.P. Nayar (1987). Endemic Plants of the Indian Region. Botanical Survey of India, Calcutta, 261pp.

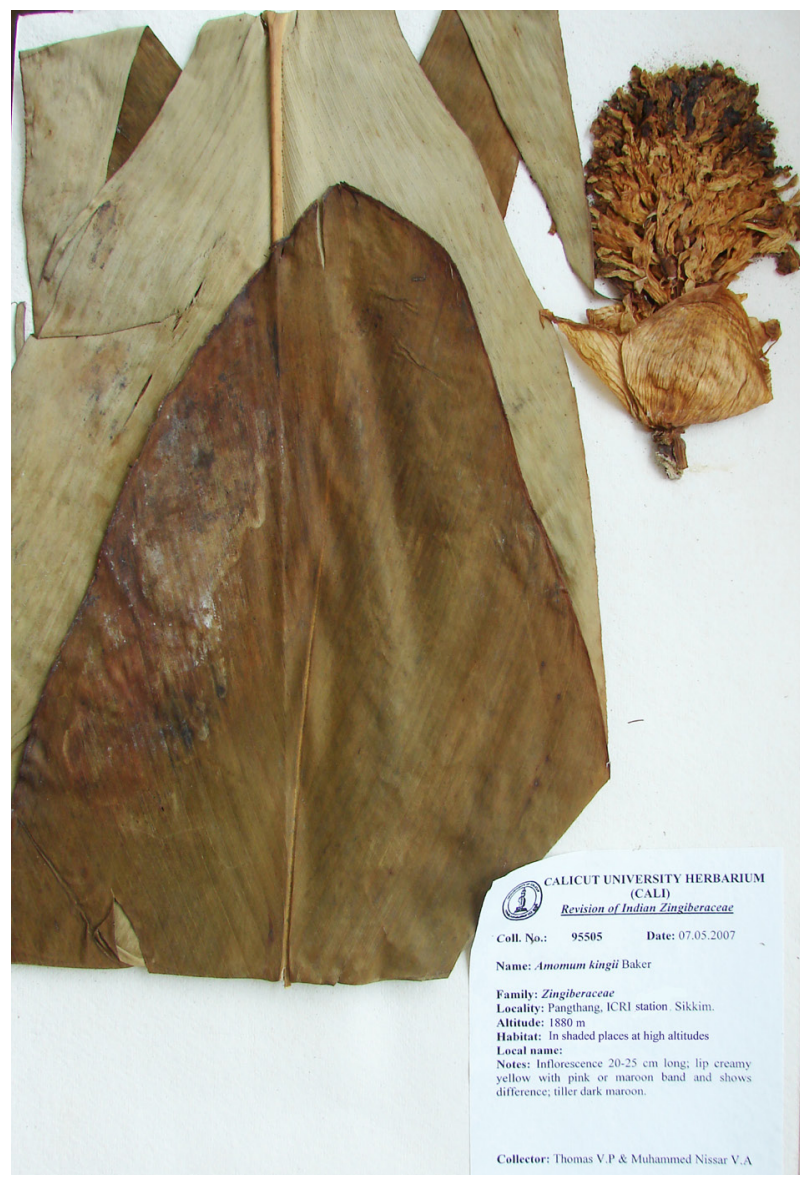

Image 3. Herbarium image of Amomum kingii

Baker, J.G. (1892). Amomum, pp. 233-243. In: Hooker, J.D. (ed.). Flora of British India, Vol. 6. L. Reeve and Co., London.

IUCN (2001). IUCN Red List Categories and Criteria, Version 3.1. Prepared by IUCN Species Survival Commission. IUCN, Gland, Switzerland, and Cambridge, United Kingdom.

IUCN (2012). Guidelines for Using the IUCN Red List Criteria at Regional and National levels Version 4. Gland, Switzerland and Cambridge.

Kumar, S. (2001). Zingiberaceae of Sikkim. Deep Publication. New Delhi, 83pp.

Sabu, M. (2006). Zingiberaceae and Costaceae of South India. Indian Association for Angiosperm Taxonomy, Calicut University, Kerala, 282pp.

Schumann, K. (1904). Amomum, pp. 221-259. In: Engler, A. (ed.). Das Pflanzenreich, IV. 46 (Heft 20). Leipzig, Berlin.

Smith, R.M. (1994). Zingiberaceae, pp. 182-209. In: Noltie, H.J. (ed.). Flora of Bhutan - Vol. 3, Part 1. Royal Botanic Gardens Edinburgh, Edinburgh.

Thomas, V.P., M. Dan, M. Sabu \& M.A. Jabbar (2010). Amomum andamanicum (Zingiberaceae): a new species from the Andaman Islands, India. Blumea 55: 295-299; http://dx.doi. org/10.3767/000651910X550954

Thomas, V.P. \& M. Sabu (2012). Two new species of Amomum (Zingiberaceae) from Western Ghats, India. Edinburgh Journal of Botany 69(2): 313-321; http://dx.doi.org/10.1017/ S0960428612000133

Tripathi, S. \& V. Prakash (1999). A new species of Amomum Roxb. from Meghalaya, India. Rheedea 9: 177-180. 